\title{
× Acknowledgments
}

I am extremely grateful to the people who have generously helped me as I worked on this book. I am particularly indebted to Ken Ito, my adviser at the University of Michigan, and to Komori Yöichi, who guided my research while I was studying at the University of Tokyo. I would also like to express my thanks to the members of my dissertation committee: Esperanza Ramirez-Christensen, Ross Chambers, and Leslie Pincus. As I revised the dissertation into a book manuscript, I have been the beneficiary of many thoughtful and careful readers, including Eileen Chow, Tom Hare, Adrienne Hurley, Shu Kuge, Daniel O'Neill, Stephen Orgel, Ann Sherif, Melinda Takeuchi, Robert Tierney, Atsuko Ueda, Patricia Welch, and Edmund White. I am especially thankful to Kathleen Geisse, Sharalyn Orbaugh, and Alan Tansman, who provided valuable suggestions for the manuscript in its final stage, and to my colleague Kären Wigen, who offered timely support as I searched for a publisher. I would also like to convey my gratitude to Naomi Kotake and Mary-Louise Munill, both of whom assisted in the search for bibliographic and visual materials, and to Joanna Sturiano, who helped in the production of the index. At Stanford University Press, special thanks are due to Muriel Bell, Carmen Borbón-Wu, and John Feneron.

Enabling my research and writing on this project have been a number of different grants. At the dissertation stage, I was the lucky recipient of a Japan Foundation Dissertation Research Grant and a Rackham Predoctoral Fellowship, which together supplied the funds that allowed me to spend two years in Japan conducting research. After returning to Ann Arbor in 1995, I received a Dissertation Write-Up Grant from the Department of Asian Languages and Cultures. At Stanford University, I spent the 1999-2000 academic year at the 
Stanford Humanities Center, where I made significant progress on expanding and revising the manuscript. In 2002 a generous grant from the John Philip Coughlan Fund facilitated the final stage of my research.

An earlier version of Chapter 3 appeared as "Tsubouchi Shōyō's Tōsei shosei katagi and the Institutionalization of Exclusive Male Heterosexuality" in Harvard Journal of Asiatic Studies, vol. 52, no. 1 (2003), pp. 69-114; and an earlier version of Chapter 6 appeared as "Sōseki Nowaki ni okeru otoko-dōshi no aijō no imi" in Bungaku, vol. 6, no. 1 (1995), pp. 84-96.

Lastly, I would like to offer my sincere thanks to my family and friends who have provided unstinting support as I worked on this project over the years.

Jim Reichert 